\title{
Financial Technology: Development of Innovative Fintech Start-Ups and Its Application in Banking System of Uzbekistan
}

\author{
Shamsiddin Amanullaevich Allayarov ${ }^{1}$; Maktuba Ravshanova ${ }^{2}$ \\ ${ }^{1}$ Ph.D., Associate Professor, Head of the Department of Management and Marketing, Tashkent Institute of Finance, \\ Tashkent, Uzbekistan \\ ${ }^{2}$ Tashkent Institute of Finance, Uzbekistan \\ http://dx.doi.org/10.18415/ijmmu.v8i9.3017
}

\begin{abstract}
In the context of globalization, labor migration, trade and capital movements, tourism, foreign investment, IT are affected by the economic growth rates of countries. Periodic disclosure of reforms in the new Uzbekistan, the beginning of socio-economic relations provided opportunities for modernization, technical and technological re-equipment of the industrial sector. In particular, the need for financial technology in commercial banks is important to conduct research in this area. The influence of fintech is beginning to be felt in the banking sector and capital markets. This article surveys its development and its impact on efficiency, banking market structure, strategies of incumbents and entrants, and financial stability.
\end{abstract}

Keywords: Financial Technology; Commercial Bank; Capital Market; Digital Economy; Financial Institutions; Blockchain; Financial Services; Financial Policy

\section{Introduction}

Today, we cannot imagine our lives without digital technologies, as a result of which there is no field left that they have not entered. In particular, the fact that the Internet revolution is being observed is creating new innovations. The main issue is to exchange information more accurately in different sectors of the economy (Allayarov: 2020). Similarly, the provision of financial and banking systems with digital technologies not only increases business productivity, but also creates many conveniences for the exchange of information between the customer and the bank.

\section{Financial Technology}

(Fintech) is used to describe new tech that seeks to improve and automate the delivery and use of financial services. At its core, fintech is utilized to help companies, business owners and consumers better manage their financial operations, processes, and lives by utilizing specialized software and algorithms that are used on computers and, increasingly, smartphones. Fintech, the word,is a combination of "financial technology".

When fintech emerged in the 21st Century, the term was initially applied to the technology employed at the back-end systems of established financial institutions. Since then, however, there has been a shift to more consumer-oriented services and therefore a more consumer-oriented definition. 
Fintech now includes different sectors and industries such as education, retail banking, fundraising and nonprofit, and investment management to name a few. Broadly, the term "financial technology" can apply to any innovation in how people transact business, from the invention of digital money to double-entry bookkeeping.

Figure 1 illustrates the major components of Fintech in a combination of two areas.

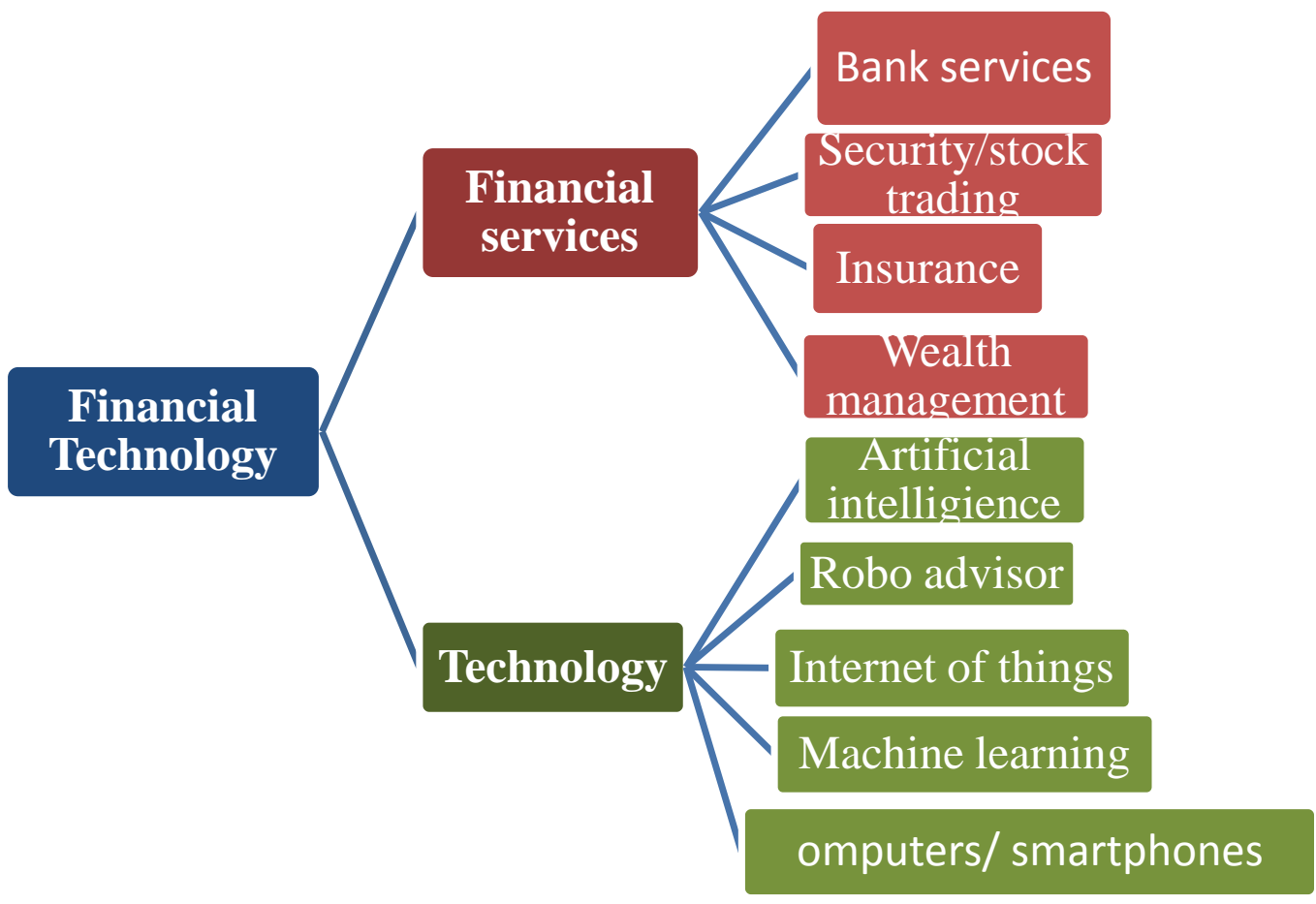

Figure 1. Fintech components (made by the author)

As can be seen, Fintech is a combination of financial services and technology. Up until now, financial services institutions offered a variety of services under a single name. The scope of these services encompassed a broad range from traditional banking activities to mortgage and trading services. The combination of streamlined offerings with technology enables fintech companies to be more efficient and cut down on costs associated with each transaction. As a result, both the bank and the customer benefit at the same time (Allayarov: 2011).

The integration of financial services and technology has led to the introduction of the following new types of services.

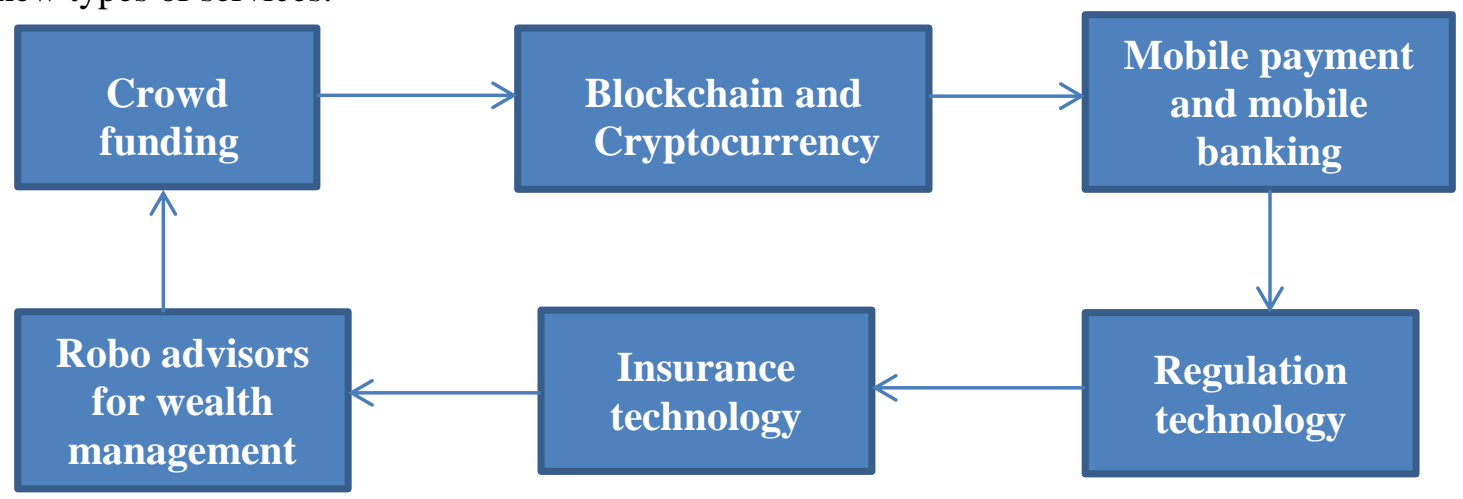

Figure 2. Examples for latest Fintech service types (made by the author) 


\section{Fintech start-ups}

The Fintech services listed above are designed to create more convenience for customers, reduce risk, create a purely competitive environment between banks, and offer a number of other benefits. All of them are widely used around the world, and a lot of work is being done to further improve or introduce new types of services. Fintech startups received \$17.4 billion in funding in 2016 and were on pace to surpass that sum as of late 2017, according to CB Insights, which counted 26 fintech unicorns globally valued at $\$ 83.8$ billion. The same firm reported that there were $39 \mathrm{VC}$-backed fintech unicorns worth $\$ 147.37$ billion by the end of 2018 .

There is no doubt that COVID-19 has had a huge impact on both consumers and business behavior, which means that companies ought to adapt as fast as possible to the new normal. Therefore, it is one of the most powerful factors which can form FinTech and banking players' actions in 2021.

In addition to the above, two-thirds of financial transactions are made online and, respectively, the fintech sector attracts about $\$ 50$ billion in investments each year. The worldwide fintech adoption rate rose to 64\% in 2020 and therefore fintech market size is projected to achieve $\$ 310$ billion by 2022 .

The main users of Fintech are diveded into four broad categories :

- B2B ( business to business) for banks;

- Business clients of banks;

- B2C ( business to consumer) for small business;

- Consumers.

Trends toward mobile banking, increased information, data, and more accurate analytics and decentralization of access will create opportunities for all four groups to interact in heretofore unprecedented ways. However, as for consumers, the majority of users includes younger people with the most technology. When it comes to businesses, before the advent and adoption of fintech, a business owner or startup would have gone to a bank to secure financing or startup capital. Now, with mobile technology, those hurdles are a thing of the past. (L.Shaulska: 2021)

In order to support new ideas in Republic of Uzbekistan, in Tashkent, announced the first fintech laboratory in the country. In 2018, Open Innovations in the Banking Sector session of the International Press Club, the first fintech laboratory of Uzbekistan was announced. The platform is designed to create and test new projects, as well as provide the necessary advice from experts and specialists. (Allayarov: 2019)

In addition, The Digital Uzbekistan-2030 project also envisages automation of economic sectors, in particular, the financial sector. According to it, each new idea of the digital economy will be analyzed and find its own confirmation.

To ensure a balance between innovation and fair competition within the financial industry regulatory sandboxes should ensure that even though Start-Ups are exempted from major regulatory requirements, there must be ways to protect the interest of both the existing businesses so that there are no disruptions, and also innovations of the Start-ups are not hindered.

\section{Fintech in banking system of Uzbekistan}

At present, a lot of work is being done in our country to transition to a digital economy, in particular, to bring it to the level of public policy and provide full support. In the words of President of 
Uzbekistan: "Of course, we know very well that the formation of a digital economy requires the necessary infrastructure, a lot of money and manpower. But no matter how difficult it is, if we don't start today, when will we start ?! It will be too late tomorrow. Therefore, the active transition to the digital economy will be one of our priorities for the next 5 years.

Digital technologies not only improve the quality of products and services, they reduce unnecessary costs. At the same time, they are an effective means of overcoming the scourge of corruption, which is the most serious problem that worries and annoys me. We all need to understand that."

As many developed countries, Uzbekistan is increasing the role of Fintech in its banking system and various sectors of the economy. On April 28, 2020, the Presidential Decree "On measures to introduce the digital economy and e-government" was adopted. According to it, by 2023 it is planned to double the share of the digital economy in the country's GDP and triple the volume of services in this area, and increase their exports to 100 million US dollars. At the same time, in 2020-2022 it is planned to implement 268 projects on further development of e-government, telecommunications, software products and information technology park, the widespread introduction of digital technologies in the real sector of the economy and agriculture and water management. (G. Shamborovskyi: 2020)

The main goal of the banking system of the Republic of Uzbekistan is to have a developed national credit system that meets international standards, to attract the free funds of the population, to create a basis for meeting the needs of the population and achieve improvement living conditions on the basis of its effective distribution. In order to achieve the desired goal, it is necessary to use financial technologies, today. Here are some examples for widely used financial programs in the banking system of Uzbekistan: iABS, NSI, Globus, ASBT, e-Personal. One of the main results of the bank's automation should be an increase in the quality of its management. The main service modules of the system provide: provision of cash services to legal entities; maintenance of correspondent bank accounts; credit, deposit, currency operations; any types of deposits of individuals and operations on them; fund operations; settlements using plastic cards; accounting functions; analysis, decision making, management, marketing, etc.

Still regulatory uncertainty a significant challenge for FinTech. Therefore, sufficient source of information on FinTech require to create a culture of compliance step by step and learn from other countries experience. Uzbekistan will also be able to solve potential problems with Fintech based on the experience of the United States, the Netherlands or other countries. (Allayarov, Sh.PhD.: 2020)

There are currently more than 30 banks operating in Uzbekistan. The indicator of availability of remote banking services covers individuals and legal entities that use banking services online. As of 1 July 2020, the total number of users of remote banking systems reached 11.7 million, of which $93.8 \%$ are individuals, and $6.2 \%$ are legal entities and individual entrepreneurs. The numbers show that, reforms in this area are attaining objectives.

\section{Conclusion and Proposals}

1. In conclusion, we can infer that FinTech as a whole is an emerging industry that's making every aspect of financial lives easier, more accessible, and faster. Therefore, regulators, banks, startups, and the government should work in cooperation to improve the support and service to fintech startups.

2. Fintech refers to the integration of technology into offerings by financial services companies in order to improve their use and delivery to consumers. It primarily works by creating new markets for them where market participants should have both financial and IT knowledge, and the services provided will be appropriate. 
3. Uzbekistan also is going to have a big step in the improvement of Fintech. Firstly Uzbekistan has to pay attention to the development of regulation regarding this. It should take into consideration the issues that may occur because of Fintech. For example, issue is the security of the data and transactions.

4. In order to achieve the desired results, it is necessary to hold seminars, courses and other events in educational institutions in order to promote and expand "digital literacy" among the general population, to involve them in the adoption of information technology. After that, the whole population will start using Fintech.

5. International experience shows that today digital technologies are developing rapidly, mainly in the scientific community and the private sector. Therefore, the state should create a favorable ecosystem by supporting innovative projects and IT companies in these areas. The government should also support modern methods of digital education in the field of innovation and digital ecosystem support.

\section{References}

Allayarov Sh.A. Features and ways to improve the current model of agricultural policy of Uzbekistan//INTERNATIONAL JOURNAL OF RESEARCH IN SOCIAL SCIENCES, (ISSN:22492496), Impact Factor (IJRSS) 7.081 for 2016// April 2017. P 212-223.

Allayarov, Sh. (2019) "ON THE INTERDEPENDENCE OF THE CONCEPTS OF "TAX CULTURE" AND "TAX DISCIPLINE"// International Finance and Accounting: Vol. 2019 :Iss. 6, Article 14. Available at: https://uzjournals.edu.uz/interfinance/vol2019/iss6/14.

Allayarov, Sh. PhD; Mirzamakhmudov, M.; and Mirzamakhmudova, M. (2020) "ANALYSIS OF REGULATORY SANDBOX IN THE NETHERLANDS THAT PROMOTE DEVELOPMENT OF INNOVATIVE FINTECH STARTUPS"// International Finance and Accounting:Vol.2020:Iss.3,Article34.Available:https://uzjournals.edu.uz/interfinance/vol2020/iss3/34

Allayarov, Sh., Allayarov S., Yuldasheva U., Madjidov N. (2020) Assessment of the effectiveness of the results of the fiscal policy of the republic of Uzbekistan// International Journal of Advanced Science and Technology Vol. 29, No. 7, (2020), pp. 7920-7926.

Allayarov, Sh., Nabiev E., Allayarov S., Amanullaeva Yu. (2020) Ways To Improve The Tax Mechanism To Ensure The Financial Security Of The Country//International Journal of Advanced Science and Technology. Vol. 29, No. 7, (2020), pp. 7849-7855.

Allayarov, Sh.PhD. (2020) Strengthening tax discipline in the tax security system: features and current problems//South Asian Journal of Marketing \& Management Research (SAJMMR). https://saarj.com. ISSN:2249-877X, Vol. 10, Issue 11, November 2020, Impact Factor: SJIF 2020=7.11, pp. 124-128.

Allayarov, Sh.PhD. (2020) The improvement of tax control in order to strengthen tax discipline in the republic of Uzbekistan// TRANS Asian Journal of Marketing \& Manajment Research (TAJMMR). https://tarj.in ISSN:2279-0667, Vol 9, Issue 11, November 2020, Impact Factor: SJIF 2020=7.209, pp. $57-62$.

Bjorn, S. a. (2019, March 10). Netherlans: Fintech 2019. Retrieved July 30, 2019, from ICLG.com: https://iclg.com/practice-areas/fintech-laws-and- regulations/Netherlands. 
Financial technology-Fintech. By JULIA KAGAN; Reviewed by ERIC ESTEVEZ. Updated Aug 28, 2020. Available at: https://www.investopedia.com/terms/f/fintech.asp.

FinTech 2021: 20 Articles for FinTech Experts. 23 December,2020. Available at:https://www.finextra.com/blogposting/19700/fintech-2021-20-articles-forfintech-experts.

Fintech Statistics. (21.06.2021). Available at: https://balancingeverything.com/fintech-statistics/.

G. Shamborovskyi, M.Shelukhin, AllayarovSh, Y.Khaustova, S. Breus. (2020) Efficiency of functioning and development of exhibition activity in international entrepreneurship// Academy of Entrepreneurship Journal (Print ISSN: 1087-9595; Online ISSN: 1528-2686) Volume 26, Special Issue 4, 2020 pp. 1-7.

Rating of commercial banks of Uzbekistan by the quality of services provided and operating activities for the first half of 2020. 21/08/2020. Available at: http://www.uzdaily.com/en/post/59372.

Regulatory overhaul needed to make the Netherlands a fintech hub - report. (2016, January 22). Retrieved June 24, 2019, from Finextra: https://www.finextra.com/news/fullstory.aspx?newsitemid=28369.

Аллаяров Ш.А. Модернизация аграрного сектора Узбекистана:проблемы и решения//Финансовий вестник-финансы,налоги,страхование,бухгалтерский учет. Индекс 45427. (Россия) 2011.№12.- c. 17-24.http://www.finance-journal.ru/index.php.

\section{Copyrights}

Copyright for this article is retained by the author(s), with first publication rights granted to the journal.

This is an open-access article distributed under the terms and conditions of the Creative Commons Attribution license (http://creativecommons.org/licenses/by/4.0/). 